\title{
Judicial Masculinity: Examining The Role And Effect of Women's Justice in The Indonesian Constitutional Court
}

\author{
Zaka Firma Aditya*, Rizkisyabana Yulistyaputri, and Abdul Basid Fuadi \\ The Constitutional Court of the Republic of Indonesia, Medan Merdeka Barat Street, Jakarta, \\ Indonesia \\ *Corresponding author
}

\begin{abstract}
.
It should be realised that Indonesia's constitutional judiciary is still and [always] identical with men. How come? during the eighty-eight years of existence, only two women had become constitutional court justice in a different generation. Whereas guarding the constitution is not only the duty of men but also women. Interestingly, of the three institutions proposing constitutional justice, only the President dared to give the judges seats to women. Does this mean that other institutions such as the Supreme Court and the House of Representatives do not support feminists entering the judiciary? or does the President just maintain the image so that he/she seen as supporting the feminist movement?. If the President fights for feminism in the judiciary, he/she should increase the quota, given that many women are interested in becoming the constitutional court justice. This article will answer how the role and influence of women justice in deciding constitutional cases. In the first part, we will discuss the reasons for the low representation of women in the Indonesian Constitutional Court. Before the conclusion, the author will discuss the role and influence of women justice in the constitutional court.
\end{abstract}

Keywords: Feminist, Women Justice, Constitutional Court.

\section{Introduction}

After the 1998 reformation, the Indonesian feminist movement was increasingly developing, not only demanding the recognition of women's rights, which [must] be equal to men in the political, legal, and social fields. More than that, the feminist movement has entered and flowed into the veins of state institutions and ministries. One of them is the birth of the Indonesian Women's National Commission, which has a feminist orientation because its founders were feminist figures in Indonesia. In its history, the National Women's Commission was born because of the persistent efforts of Indonesian feminist figures, such as Professor Saparinah Sadli (chair of the University of Indonesia Women's Studies), Ita F. Nadia, Sinta Nuriyah Abdurrahman Wahid, Kuraisin Sumhadi, Mayling Oey, Mely G. Tan, Kamala Chandrakirana, and Smita Notosusanto (Arivia \& Subono, 2018:19). The commission established as an independent state institution that aims to strengthen women's rights in 


\section{2nd Global Conference on Women's Studies}

10-12 June 2021

Berlin - Germany

Indonesia. Presidential Decree No. 181 of 1998 and Presidential Decree No. 65 of 2005 passed this institution.

In that era, women policy agents emerged in the government/state or what was known as state feminism or femocrats. They are feminists who work from within the state apparatus to advance women's rights, pro-feminist policies, and political representation (Lovenduski, 2005: 3-5). This state feminism never thought during the New Order because there was great suspicion that the state wanted to silence women's rights. Sure enough, the government provided financial support to women's organizations at that time so that they forced to support the government's development goals. Women's organizations are segregated into and coordinated by the Office of the Minister for Women's Roles (Suryakusuma, 2011: 18).

The message brought by the Indonesian feminist movement agents was then first captured by President Abdul Rahman Wahid by issuing Presidential Instruction Number 9 of 2000 concerning Gender Mainstreaming in National Development. This instruction addressed to Ministers, Government agencies, Military Commander, Chief of Police, Attorney General's Office, Governor, and Regent/Mayor. As a result, it was not only the institutions that were the object of the presidential instruction that succeeded in passing female representation. However, Megawati Soekarno Putri as an influential woman also became the first Indonesian female President. It can be said to be the most outstanding achievement of the Indonesian feminist movement.

Unfortunately, other state institutions cannot transmit this success. Because, even though it was agreed with the figure of 30 per cent as the minimal limit the representation of women, in practice, women's representation is still deficient. For example, members of the legislative body were only able to fulfil 19-20 per cent of women's representation from 2004-2019, the Supreme Court was only able to fulfil 11 per cent of women's representation from 2004-2020, and the Constitutional Court was only able to fulfil 11 per cent of women's representation from 2009-2020.

Worse yet, Megawati was the first woman president born of the spirit of the feminist movement, does not take a pro-feminist policy. It can saw when the Constitutional Court established. President Megawati did not appoint a single women representative to serve as a constitutional Justice in the first 2003-2008 term. Megawati appointed men judges like Professor Jimly Asshiddiqie, Professor Abdul Mukthie Fadjar, and Professor H.A.S. Natabaya. Practically, in that first period, all constitutional justice were men. It makes the author[s] more convinced that the Indonesian judiciary (especially the Indonesian constitutional court) tends to be masculine. Woman representatives only present during the second period with the appointment of Professor Maria Farida as constitutional justice by President Susilo Bambang Yudhoyono.

The election of Maria Farida as a woman justice at the Constitutional Court can be said to be the second most prominent achievement of feminists after Megawati. Especially if you look at the outstanding performance of Justice Maria, who often expresses dissenting opinions and different reasons (concurring opinion) from other judges when deciding cases. Even in several decisions, she not only using a normative perspective, but also uses her female perspective. Especially regarding cases that related to children and women. As a woman 


\section{2nd Global Conference on Women's Studies}

10-12 June 2021

Berlin - Germany

justice, she was the only one who still thinks of women affirmative action to remain a permanent policy in the era of democracy.

After justice Maria retired, President Joko Widodo appointed Professor Enny Nurbaningsih to be the next woman justice. Interestingly, apart from professor Enny, there were two other candidates, i.e. Professor Ni'matul Huda and Professor Susi Dwi Harianji. It is sufficient to show that there is already awareness from the government (president) regarding the importance of a women figure in the constitutional judiciary. Although, its awareness not followed by other state institutions that have also proposed constitutional justice, such as the House of Representatives and the Supreme Court. Moreover, in its way, Justice Enny also several times expressing different views (dissenting) when deciding cases. It is proof that even women justice can stand alone, think independently, critically and independently without having to follow the votes of the majority of other judges [male constitutional justice].

This article will answer how the role and influence of women justice in deciding constitutional cases. In the first part, we will discuss the reasons for the low representation of women in the Indonesian Constitutional Court. Before the conclusion, the author[s] will discuss the role and influence of women justice in the constitutional court.

\section{The Low Representation and The Importance of Women Justice In The Constitutional Court}

The Constitutional Court has the primary competence to maintain the constitutionalism of state life, in line with the constitution. One of its powers is to examine laws against the 1945 Constitution (judicial review). So that, it is necessary to consider the factors that might influence a fair judicial review process. To be unambiguous, the judicial review process, apart from requiring competence in the legal field, the actors of the judicial power must reflect the proportional representation of various groups. One of the things that need attention is the need for gender awareness in the judiciary (Duban \& Radačić, 2017). Nowadays, there is [only] one woman constitutional justice who is active in the composition of Indonesian Constitutional Justices. It might see as a problem due to only one female perspective in the Constitutional Court. This problem is more evident factually as seen from the dissenting opinion of the only woman Constitutional Justice when there was a judicial review case on the Pornography Law (Faiz, 2018). The following fig.1 can see the representation of woman justice in the constitutional court.

Figure 1. the representation of constitutional Court woman justice

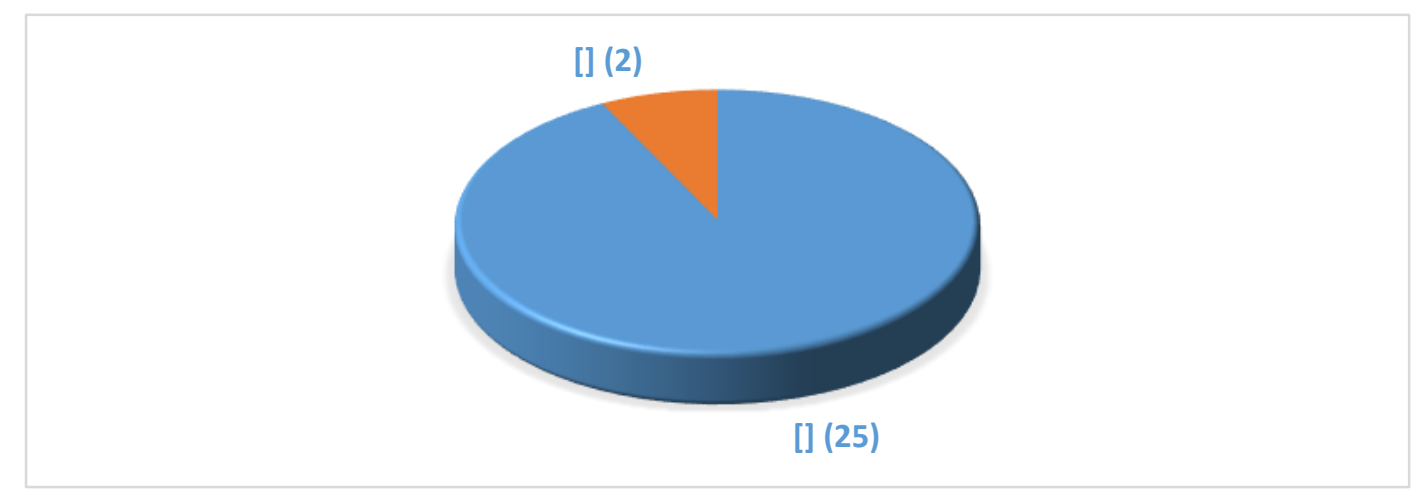




\section{2nd Global Conference on Women's Studies}

10-12 June 2021

Berlin - Germany

The judicial power structure in Indonesia recognizes two branches of power, namely the Supreme Court and the Constitutional Court. Interestingly, in the current period, among the 45 Supreme Court Justices there are five Women Supreme Justice (Mahkamah Agung, 2020). According to Pompe's notes, the Indonesian Supreme Court has had the first Women Supreme Court Justice since 1968, i.e. Justice Sri Widoyati Wiratmo Soekito (Pompe, 2005). Furthermore, until 2010, there were 28 Women Supreme Court Justices in Indonesia. Meanwhile in the constitutional court, at the age of 18 there are only two constitutional judges, each serving in a different period and which is the President's proposal, while other proposing institutions have never sent female Constitutional Justices to the Constitutional Court [see fig.1].

Studies on women's representation in the judiciary are not as attractive as studies on women's representation in other government institutions, especially the legislature. In the Indonesian context, various studies have been present that highlight the word of women in parliament (Hardjaloka, 2012). Globally, it was only in 1893 that women could get the political right to vote. Interestingly, women's political involvement still discussed, and women still need efforts to fully obtain their civil, political, social, economic and cultural rights. The majority of society still places women in second class positions. Ida Fauziyah quoted Virginia Wolf as saying there is a separation of public and domestic spaces for women. Women do not have access to the public sphere, while in the domestic sphere, women also do not have the power to decide or rights to property (Dibattista, 2009; Fauziyah, 2015).

In addition, the dominant institutions such as family, community, and environmental education has traditionally still very patriarchal, so that more causes difficulties women play in public spaces. These dominant institutions play an essential role in the birth of policies for all citizens, including women. Of course, these policies tend to be men because only men are involved in the decision-making process. Men are often assumed to be the head of the family, representing the family, even though this is related to aspects of women's lives. It is through this masculine policy that male domination becomes increasingly legitimate.

The validity of male domination wrapped in social, cultural, legal, health considerations, and even religious reasons. For example, the Sasak community knows the tradition of 'merarik', which is a tradition of the marriage process preceded by carrying away or 'kidnapping' a girl before the marriage procession carried out in a religious and national law manner. Although, in general, this 'merarik' marriage considered a mere formality. The parents whose daughter run away may refuse to marry and become guardians for their daughter because their daughter wants to finish school and is not old enough to marry. But usually, because of local customs, the girl's parents were reluctant to prolong the matter and agreed to marry off her daughter. It is not uncommon for them to blame when they question this. Psychologically and sociologically, this can bury the dreams, aspirations and motivations of parents and children to obtain higher education. Living in such a social and cultural environment will make it difficult for women to take roles in the public sphere.

Problems that hamper women's role in public spaces are social and cultural issue and the religious domain. There are still many fuqaha (muslim legal scholar) circles that oppose the role of women in the public sphere. The textual understanding of the Qur'an verses, which positions men as leaders for women, is the primary basis for this argument. On the other hand, the Qur'an itself bears witness to a female figure who becomes the highest political leader 


\section{2nd Global Conference on Women's Studies}

10-12 June 2021

Berlin - Germany

who leads 'the country of Saba'. Even though in contemporary developments, we can classify Muslim scholar circles into three parts, namely those who allow, some are not allowed, and some are moderate. However, the public role played by women is still debatable.

Health reasons do not escape from being an obstacle to the role of women in the public sphere. Most families yearn for pregnancy and childbirth (especially the first child), but for working women, pregnancy, which is a biological nature, is a dilemma in itself. The different biological anatomy between men and women is a significant factor in determining the social roles of the two. In the end, it is men who have a prominent role in society because they are considered more potent and more productive. Reproductive organs owned by women considered to limit women's movement, such as pregnancy, childbirth, and breastfeeding, while men do not have these reproductive functions (Fujiati, 2014). So those men are supposed to take roles in the public sector, while women take on roles in the domestic sector.

Political representation of women in the Indonesian legislative body is quite encouraging. The average quantity of women representatives in parliament in each period has almost always increased. It cannot separate from the affirmative policy contained in the general election regulations. Law Number 7 of 2017 concerning General Elections requires political parties to nominate 30 per cent female legislative candidates in each electoral district. This law strengthened by the General Election Commission's regulation, which provides sanctions for political parties that do not meet the 30 per cent quota of female candidates to be unable to participate in voter competitions in the electoral district. Such sanctions are effective in forcing political parties to carry out an affirmative action policy for representation in the candidate lists they compile (Arivia \& Subono, 2018).

Table 1. women representation in Indonesian parlemen

\begin{tabular}{|c|c|c|c|c|}
\hline Period & Women & \% & Men & \% \\
\hline $1950-1955$ & 9 & $3,7 \%$ & 236 & $96,3 \%$ \\
\hline $1955-1960$ & 17 & $5,9 \%$ & 272 & $94,1 \%$ \\
\hline $\begin{array}{c}\text { Konstituante) } \\
\text { (1956-1959 }\end{array}$ & 25 & $4,9 \%$ & 488 & $95,1 \%$ \\
\hline $1971-1977$ & 36 & $7,3 \%$ & 460 & $92,7 \%$ \\
\hline $1977-1982$ & 29 & $5,9 \%$ & 460 & $94,1 \%$ \\
\hline $1982-1987$ & 39 & $7,8 \%$ & 460 & $92,2 \%$ \\
\hline $1987-1992$ & 65 & $13,0 \%$ & 435 & $87,0 \%$ \\
\hline $1992-1997$ & 62 & $12,4 \%$ & 438 & $87,6 \%$ \\
\hline $1997-1999$ & 54 & $10,8 \%$ & 446 & $89,2 \%$ \\
\hline $1999-2004$ & 46 & $9,2 \%$ & 454 & $90,8 \%$ \\
\hline $2004-2009$ & 65 & $13,0 \%$ & 435 & $87,0 \%$ \\
\hline $2009-2014$ & 101 & $18,0 \%$ & 459 & $82,0 \%$ \\
\hline $2014-2019$ & 97 & $17,3 \%$ & 463 & $82,7 \%$ \\
\hline $2019-2024$ & 118 & $20,5 \%$ & 457 & $79,5 \%$ \\
\hline
\end{tabular}

Unfortunately, this policy is counterproductive to the general election system adopted in Indonesia in the form of open proportionality. In such a system, there is no protection for a list of female candidates. The 30 per cent quota stipulated in candidacy becomes meaningless when the election results counted to be converted into parliamentary seats. During such a 


\section{2nd Global Conference on Women's Studies}

10-12 June 2021

Berlin - Germany

situation, we then realized the importance of having women in the composition of Constitutional Justices. On September 3, 2008, the Indonesian Constitutional Court registered petition 22/PUU-VI/2008 questioning the general election system used in Indonesia. In the end, although other constitutional justices argued that the electoral system with the most votes was the electoral system that should operate in general elections in Indonesia, the only Indonesian Women Constitutional Justice expressed a different opinion.

Could gender influence the judicial process? Although generally, the law is assumed to be neutral, objective, and impartial, there is an assumption that gender has no effect or negligible influence on the judicial process. But these questions and hypotheses immediately generate new questions. Is it possible that legal practitioners' implementation of the law (including judges) influenced by social norms can be conveyed impartially? The above events may reflect that Judges (and other legal professions) not only bring academic competence, professional experience, legal perseverance and goodwill to their work, they also bring their values, beliefs and life experiences.

Although Judges also bring their values, beliefs and personal experiences with them. However, democratic justice institutions are committed to the principles of justice and impartiality, Judges (and other legal professions) trained to apply the law objectively. Many consider and believe that the appointment of more female judges will impact the judicial decision-making process itself and the development of substantive law. As previously mentioned, this flows from the belief that women view the world and what happens in it from a different perspective than men. Some define differences in perspective only because women do not accept men's perceptions and interpretations of events as norms or as objective reality.

Claims about the differences that female judges may make, for example, have been made by Madame Justice Bertha Wilson of the Canadian Supreme Court when delivering her famous lecture, 'Will Women Judges Really Make a Difference?'. Since then, many articles have addressed the same theme. In brief, as Hunter notes, there are six arguments about the importance of women's involvement in the judiciary as judges (Hunter, 2015:119):

1. The presence of female judges increases the legitimacy of democracy in the judiciary because female judges are seen as more representative of society than courts without female judges. Ideally, women should be represented in the judiciary in the same number as men or a proportion of society.

2. The presence of female judges indicates an equal opportunity for women in the legal profession and shows that appointing judges is fair, meritocratic and nondiscriminatory.

3. The presence of female judges provides encouragement and active assistance for women in the legal profession, law students, thus enabling gender balance in the judiciary to be improved.

4. Female judges tend to empathize more with female plaintiffs and witnesses, including crime victims, and provide a better courtroom experience for the parties to the trial.

5. Those female judges will civilize their male colleagues not to tolerate sexist comments, stereotypes and gender bias. 


\section{2nd Global Conference on Women's Studies}

10-12 June 2021

Berlin - Germany

6. Substantively, female judges will bring gender sensibility into the decision-making process and thus (at least sometimes) change the outcome of cases.

The low representation of women in the judiciary has led to calls for more excellent representation of women based on the argument that women have a different voice than men. However, according to the author, a more important argument to encourage more excellent representation of women in the judiciary is the need for diversity in the judiciary. Women judges are indispensable for the Constitutional Court to increase public confidence in the court's ability to respond to legal problems of all classes of citizens. Even though the law is generally assumed to be neutral, the law's actualization always depends on the sociological conditions the law is formed and applied. Quantitatively, we may only find a few "different voices" from Indonesian Women Constitutional Justices. So it is easy to conclude that gender representation does not affect the judicial process. However, with further research into decisions made with total votes, the existence of a Constitutional Justice will likely be able to influence the outcome of a case. Because sometimes discrimination does not happen deliberately, but instead with the stereotype of legal neutrality has unconsciously marginalized the role of women from the judiciary on the grounds of impartiality.

\section{The Role and Influence of Women Justice In The Constitutional Court Decision}

Female justice plays a vital role in colouring the judicial institution and colouring the 'taste' of the legal considerations of a decision. Through the maternal perspective, female justice can explore truth values that are not accessible to male judges. The sense of legal consideration felt when they made a dissenting opinion. According to Black Law Dictionary 9th Edition (Bryan A. Garner, 2009), dissenting opinion is an opinion by one or more judges who disagree with the decision reached by the majority. -- Often shortened to dissent. -- Also termed minority opinion. It can see that the dissenting opinion practice carried out by female justice is related to the freedom of judges in deciding cases and freedom of thought, in which case a female justice can stand alone and did not bound by the majority opinion.

Interestingly, even though the constitutional court only has two female justice [see fig.1], it dares to dissent opinions and concurring opinions several times in the judicial review decisions. In the constitutional court, the dissenting opinion of constitutional justice is the essence of the judge's personal freedom to find material truth (Firdaus et al., 2020). For constitutional justice, individually, the dissenting opinion and concurring opinions announced are academic and moral responsibilities for the decision making process in examining a case (Faiz, 2018). Until now, there are no laws and regulations in Indonesia that clearly regulate dissenting opinions. Article 14 paragraph (3) Law Number 48 the Year 2009 on Judicial Power states that "In the event that a deliberative meeting is not reached, the unanimous opinion of the judge must be included in the decision".

According to Faiz, Justice Maria has issued at least twenty dissenting/concurring opinions. It consists of three concurring opinions that are singular in the decision, six dissenting opinions which are also singular in the decision, six dissenting opinions written together with other constitutional judges in the decision, and five dissenting opinions written separately together with other dissenters in the decision (Faiz, 2018). 


\section{2nd Global Conference on Women's Studies}

10-12 June 2021

Berlin - Germany

Justice Maria's first dissenting opinion was expressed in decision Number 22-24/PUUVI/2008 regarding the Review of Law Number 10 of 2008 concerning the General Election of Members of the People's Representative Council, Regional Representative Council, and Regional People's Representative Council against the 1945 Constitution, Decision Number 22-24/PUU-VI/2008 regarding the Judicial Review of Law Number 10 of 2008 concerning the General Election expressed Justice Maria's first dissenting opinion. In that decision, she explained that the issue related to women's quota is something that must be fought for because it is a constitutional right to achieve equality in the development of the Indonesian nation as a whole [see page 109-110 of its decision]. Justice Maria has an opinion by quoted Hanna Pitkin (1967) that the quota of women is based on several arguments as follows..

1. Women represent half of the population and have the right to half of the seats (justice arguments);

2. Women have different experiences from men (biologically and socially) who represented (experience argument). In line with this argument, women can enter positions of power because they will be bound in different politics;

3. Women and men have a conflict of interest so that men cannot represent women (interest group argument);

4. Women politicians represent essential role models in encouraging other women to follow. The core idea behind election gender quotas is recruiting women into political institutions and ensuring that women not isolated in political life.

Regarding the women's quota, she argued that the change in the elective mechanism to become the 'most votes' in the Legislative Election Law, in fact, negates affirmative action for female candidates in the legislative elections.

Still, regarding women, Justice Maria has a dissenting opinion on Decision Number 10-1723/PUU-VII/2009 concerning Judicial Review of Law Number 44 of 2008 concerning Pornography. In her dissenting opinion page 393-394, she emphasized beforehand that her different view does not mean that she supports matters related to pornography. She emphasized that:

As a woman, mother of three children, and teacher of thousands of students whom I have fostered over the past 24 years, since I served at my alma mater, the University of Indonesia and several other universities, I do not want and do not wish to have children. -my children, my students, even other Indonesian children are affected, fall, or fall into a world related to pornography or other things that violate ethics and morals. I believe that the problem of pornography cannot be allowed to grow and develop to poison our young generation. However, the formation of a modest regulation will not change the problem of pornography to become less in society.

Furthermore, she argued that of the seven principles for the formation of statutory regulations, i.e. the principle of clarity of objectives, the principle of appropriate institutional or forming organs, the principle of conformity between types and content of content, the principle of being enforceable, the principle of utility and usability, the principle of clarity of formulation, and the principle of openness. Unfortunately, the principle of the appropriate institution only fulfilled in the formation of Law Number 44 of 2008 concerning Pornography. In addition, she also argued that several formulations in the quo law could cause legal uncertainty in their understanding, including Article 4, Article 6, Article 20, Article 21, Article 23, and Article 43. 


\section{2nd Global Conference on Women's Studies}

10-12 June 2021

Berlin - Germany

The pornography regulation itself has regulated in various existing statutory regulations, such as the Criminal Procedure Code, the Child Protection Law, the Press Law, etc. She questioned the reasons for the formation of Law Number 44 of 2008 concerning Pornography. Then, she asked two big questions (Fajar Laksono, 2018: 32-33), namely:

1. Is it only because these regulations do not use the term "pornography" do they carry out the crime of decency or other things that the Pornography Law is so essential to formulate?

2. Is it because the implementation of the regulation did not go well that the Pornography Law needs to form? Or, to put it more briefly, because of the lack of legislation or the weak implementation of laws?

Furthermore, Justice Maria wrote her defense of women in dissenting opinion as follows. "... That those who are directly affected by the prohibitions in the Pornography Law are women and children. So where is the protection of the women in question." According to Fajar Laksono (2018), this sentence can be understood that Justice Maria assesses women and children who have the most potential to be violated from the pornography law. In addition, the pornography law does not indicate an intention to protect marginalized people, i.e. children and women.

In the Constitutional Court Decision Number 46/PUU-VIII/2010, Justice Maria has a concurring opinion. The concurring opinion is an opinion/decision written by a judge or more who agrees with the majority opinion of the panel of judges in a case but has different reasons (Adam, 2017; Mahdi, 2011). In this decision, she argued that the rights of children born outside of marriage based on the Marriage Law remain the obligation of both biological parents, not only the mother's responsibilities. In her opinion, based on a sociological review of the institution of marriage in society, the validity of marriage according to specific religions and beliefs cannot directly guarantee the fulfilment of the civil rights of wives, husbands, and children born from such marriages due to the implementation of norms. Religion and customs in society entirely left to individual awareness and public awareness without being protected by an official (state) authority with coercive power.

Marriages not based on the Marriage Law make a child born from such a marriage can cause the child's relationship to be not recognized with his biological father. The biological father's obligation to fulfil the child's civil rights cannot prosecute. She said that it was not suitable for the child to share the losses caused by both parents' (marriage) act. If it's considered a sanction, both state law and religious law (in this case, the Islamic religion) do not recognize the concept of children having to share the sanctions due to their parents' actions or what is known as 'inherited sin'. At the end of her concurring opinion, Justice Maria stated: "Therefore, in my opinion, the fulfillment of the rights of children fulfilment a marriage, regardless of whether the marriage is legal or not according to state law, remains the obligation of both biological parents."

Not only the women and children cases, but Justice Maria also gave her own dissenting opinion on general elections issues. In the Constitutional Court Decision Number 14/PUU$\mathrm{XI} / 2013$, she believed that the petition should have rejected entirely. It is different from the holding in that decision which states that the petition partially granted. According to her, on a delegation basis, the 1945 Constitution has handed over the authority to the legislators to regulate the procedures for implementing the Presidential Election and further provisions 


\section{2nd Global Conference on Women's Studies}

10-12 June 2021

Berlin - Germany

regarding general elections. Apart from the possibility of various difficulties that will face in holding the General Election separately as currently held or held simultaneously as requested by the Petitioner, this is not a matter of norm constitutionality but is a choice of shaping legal policies. So that, it becomes an open legal policy for the formers of the Law to formulate the best mechanism for general election procedures, including in determining the time between one election and another.

Together with Justice Saldi Isra and Justice Suhartoyo, she stated that the verification of political parties, both administrative and factual, is referred to in the Constitutional Court Decision Number 53/PUU-XV/2017. It is part of the design to strengthen the presidential government system, eliminating the need for verification, either administrative and factual, for all political parties that wish to participate in elections. It is clear that the essential meaning of political party simplification in the presidential government system [see Constitutional Court Decision Number 55/PUU-XVIII/2020]. It can be view, to strengthen the presidential system, the constitutional court should not abolish the provisions regarding the obligation to verify political parties because it will change and move the simplification of political parties in a different direction.

We can see that Justice Maria's appointment, which Justice Enny later replaced, is a manifestation of the role of women in the Indonesian judiciary, especially in the Constitutional Court. When viewed from the dissenting opinion and concurring opinion of the two Constitutional Justices, it will see that there is a spirit of struggle from a woman. Even in Decision Number 10-17-23/PUU-VII/2009, Justice Maria started her dissenting opinion, with the sentence 'As a woman, mother of three children, and teacher of thousands of students ...' clearly proves that Judge Maria Farida used her maternal side, her femininity when making these different opinions.

Women, especially workers in both the public and private sectors, are often said to have multiple roles - the first role in the domestic environment of the family, either as a mother or wife. The second role is as a worker. A study of several pieces of literature by Robbins (1998) regarding issues of gender and leadership suggests two conclusions. First, equating men and women tends to ignore the differences between the two. Second, the difference between women and men is that women have a more democratic leadership style, while men feel more comfortable with a directive style (emphasizing instructional ways) (Nuryati, 2016:177). As leaders, women tend to adopt a more democratic leadership style by encouraging participation, sharing power and information, and increasing the 'benefit' to their followers. They tend to lead through engagement or empowerment and based on charisma, expertise, contacts, and interpersonal skills in influencing others. On the other hand, men tend to use a style based on control and command. They are more based on the position of formal authority as the basis for him to exercise influence (Nuryati, 2016:178).

\section{Conclusion}

The women representation in the Indonesian constitutional court still low. It proved that of the twenty-seven constitutional justice who have been and are currently serving, there are only two female figures, i.e. Professor Maria Farida and Professor Enny Nurbaningsih. Awareness of the proposers of the constitutional judges become a significant problem. Of the three institutions proposing constitutional justice, only the president is still [sufficiently] aware of the importance of involving feminist figures in the world of constitutional justice. 


\section{2nd Global Conference on Women's Studies}

10-12 June 2021

Berlin - Germany

However, this does not mean that the position of women justice lower than men justice. Because in fact, it is women judges who have high sensitivity in deciding cases related to women and children. In fact, in two terms as a constitutional justice (2008-2018), Professor Maria has produced 20 dissenting opinions, almost half of which are defenses the women and children rights. Decision Number 10-17-23/PUU-VII/2009, 30-74/PUU-XII/2014, and 46/PUU-VIII/2010 are some examples where Justice Maria uses her mother tongue and maternal perspective through dissenting opinions.

Feminist nuances, from the various dissenting opinions and concurring opinions of women Constitutional Justices as described above, can illustrate how the "conscience of women" is also present in a judicial institution's decision. Although in the general dissenting opinion itself does not affect the outcome of a decision, at least the dissenting opinion from female judges will continue to describe the existence of a different point of view, a mother's point of view, a woman's point of view.

\section{Acknowledgment}

This paper is an output of the research project support by Center for Research and Case Analysis-The Constitutional Court of The Republic of Indonesia. The author[s] would like to thank The Constitutional Court of The Republic of Indonesia who has provided funding for this research and also for this conference.

\section{References}

Adam, H. (2017). Dissenting Opinion Dan Concurring Opinion Dalam. Jurnal Al-Jinayah, $3(2)$.

Arivia, G., \& Subono, N. I. (2018). Seratus Tahun Feminisme di Indonesia; Analisis terhadap Para Aktor, Debat, dan Strategi. FES Indonesia, 1-28. https://library.fes.de/pdffiles/bueros/indonesien/15114.pdf

Bryan A. Garner. (2009). Black's Law Dictionary. West Publishing.

Dibattista, M. (2009). Virginia Woolf. The Cambridge Companion to English Novelists, 361376. https://doi.org/10.1017/CCOL9780521871198.023

Duban, E., \& Radačić, I. (2017). for Judges and Prosecutors on Ensuring Women 'S Access.

Faiz, P. M. (2018). Dari Concurring Hingga Dissenting Opinion. Serviam: Pengabdian Dan Pemikiran Hakim Konstitusi Maria Farida Indrati, 3-24.

Fajar Laksono. (2018). Bahasa Perempuan dalam Putusan Mahkamah Konstitusi. In Serviam: Pengabdian Dan Pemikiran Hakim Konstitusi Maria Farida Indrati (pp. 32-33). CV Anugerah Utama Raharja.

Fauziyah, I. (2015). Geliat Perempuan Pasca-Reformasi; Agama, Politik, Gerakan Sosial. LKIS PELANGI AKSARA.

Firdaus, S. U., Anjelina, P., \& Kurniyanto, R. (2020). Peran Dissenting Opinion Hakim 


\section{2nd Global Conference on Women's Studies}

10-12 June 2021

Konstitusi Dalam Pembaharuan Hukum Nasional. Jurnal Penelitian Hukum De Jure, 20(10), 1-10.

Fujiati, D. (2014). Relasi Gender Dalam Institusi Keluarga Dalam Pandangan Teori Sosial Dan Feminis. Muwazah, 6(1), 203-224.

Hardjaloka, L. (2012). Potret Keterwakilan Perempuan dalam Wajah Politik Indonesia Perspektif. Jurnal Konstitusi, 9(15), 28.

Hunter, R. (2015). More than just a different face? Judicial diversity and decision-making. Current Legal Problems, 68(1), 119-141. https://doi.org/10.1093/clp/cuv001

Lovenduski, J. (2005). , State Feminism and Political Representation. Cambridge University Press.

Mahdi, I. (2011). Hukum Tata Negara Indonesia. Teras.

Mahkamah Agung. (2020). Peradilan Modern Berkelanjutan Optimalisasi Laporan Tahunan 2020 dalam suasana Covid-19.

Nuryati. (2016). Feminisme Dalam Kepemimpinan. Istinbath, 15(2), 161-179.

Pitkin, H. F. (1967). The Concept of Representation. University of California Press.

Pompe, S. (2005). The Indonesian Supreme Court: a Study of Institutional Collapse. Cornel University.

Suryakusuma, J. (2011). Ibuisme Negara Konstruksi Sosial Keperempuanan Orde Baru. Komunitas Bambu. 